\title{
A Certain Seminal Character of Profit which We Commonly Call "Capital": Peter of John Olivi and the Tractatus de contractibus
}

Giuseppe Franco ${ }^{1, *}$

Peter Nickl2,*\%*

${ }^{1}$ Faculty of Theology, Catholic University of Eichstätt-Ingolstadt, Eichstätt, Germany; Faculty of Philosophy, University of Salento-Lecce, Italy 2Department of Philosophy, University of Regensburg, Regensburg, Germany

Received December 10 2017; Accepted January 92018

Abstract: Tractatus de contractibus shows that there are mainly three fundamental economic views that characterize the originality and the acuteness of Olivi's thought: a subject-based theory of value, a theory of just price, and the theoretical-systematic use of the concept of capital. Olivi's distinction between simply sterile money and fertile, lucrative money - called capitale (capital) - is central. His - at that time revolutionary thought challenges the theory of money as a mere means of exchange; he acknowledged the legitimacy of trade and the added value (valor superadiunctus) of capital. Thus, he allowed a price as compensation or as remuneration for the owner's foregone use of the capital. This is not a mere scholastic subtlety, but it is a serious attempt to grasp different phenomena with different concepts.

Keywords: Peter of John Olivi • Economic ethics • Just price • Theory of value • Theory of capital

\section{Introduction}

The time from the 12th to 15th century in Europe was characterized by deep cultural, social, socioeconomic, and religious-political changes. Long-distance trade is becoming more and more important; credit and money economy are developing; the markets are becoming centers of attraction; and tradesmen are playing an essential part in economic life as well as in politics and society. In this time of epoch-making upheavals, the first forms of a new civic society arose. But this did not happen without massive social fractures, so that - as an immediate reaction - mendicant and preacher orders were found. They applied their actions exactly to the deplorable state of affairs and tried not only to reflect the misery intellectually but also to relieve it practically. Research has shown that some of the earliest traditions of market economy are rooted - in many aspects in scholastic philosophy and theology, not only in the Franciscan and Dominican school of the 13th and 15th century but also in the Spanish and German tradition of late scholasticism (Höffner 1941/2014; Bruni and Smerelli 2009; Bazzichi 2013; De Roover 1974; Heusinger 2009; Lambertini 2017; Langholm 1992, 1998; Melé 2013; Spicciani 1977, 1990a; Todeschini 1994, 2004). Philosopher such as Peter of John Olivi, Antoninus of Florence, Bernardino of Siena, Gabriel Biel, Conrad Summenhart, Luis de Molina, Francisco de Vitoria, and others made important contributions to economic analysis, for instance, by formulating the principle 
of competition, the theory of capital, the conceptual distinction between usury and interest, the right of property, the theory of just price, the theory of money, the doctrine of subjective value, etc.

Thus, scholasticism, or late scholasticism, is an interesting chapter in the history of economic thought; its suggestions and ideas are far from exhausted. The Franciscans, for instance, felt compelled by their understanding of poverty to tackle economic issues - consequently, they contributed to the creation of the Western economic vocabulary and economic analysis. Their views were always focused on ethical aims as the service of the society; their primary goal was the claim that the behavior of tradesmen ought to be determined by considerations of justice. The economic ethics of the exponents of the Franciscan school should sustainably influence economic as well as theological traditions of thought (Langholm 2009; Bazzichi 2015). Indeed, the view that economy is a place of "reciprocity" and "gratuity" is one of the central foundations of European economic culture. The scholastic philosopher who combined speculative activities with the pastoral practice of everyday life accidentally turned out to be valuable economic pioneers. They succeeded in promoting the economic and civic development of the social system.

An overview of the 13th century, more precisely into the thought of Peter of John Olivi (1248-1298), has been revealed in this paper. As a theologian and philosopher, Olivi was one of the main exponents of the Franciscan tradition; he was one of the most controversial and most original philosopher of his age. Because of his rigorous interpretation of perfect poverty and the rule of the order, as well as because of his theological positions concerning the unity of soul and body and the question of papal infallibility, Olivi was repeatedly accused and eventually condemned as a heretic or a sect founder. He went down in history as the man who had almost split the Franciscan order claiming a strict interpretation of the rule of poverty, which to the eyes of superiors of the order and popes seemed old fashioned. His writings were confiscated. After his death, his monumental Lectura super Apocalipsim (Olivi 2015) was also condemned as heretic - a negative evaluation that still now has its effects on the state of research about Olivi and on the possibilities of editing his works. It is true that international research on Olivi has intensified in the past 40 years, but a critical edition and translations of his spiritual-theological writings are still lacking.

Olivi's Tractatus de contractibus deserves special attention. This treaty about economics and economic ethics has three parts: De emptione et venditione (on purchases and sales), De contractibus usurariis (on usurious contracts), De restitutionibus (on restitutions) Historic research for a long time ascribed Olivi's thought Bernardino of Siena (1380-1444) and Antoninus of Florence (1389-1459). This is due to the fact that these two thinkers took over many passages of the Tractatus verbatim without quoting Olivi probably because the writings of Olivi were forbidden. When Pacetti (1936) was preparing the critical edition of the Opera omnia of Bernardino, a manuscript of Olivi's Tractatus was found in the private library of the preacher of Siena which Bernardino had used composing his Sermones (sermons). Furthermore, he had written notes and references and made underlinings in the margins of the manuscript. After that, the Dominican Antoninus availed himself of the writings of Bernardino, so that Olivi's thought, anonymously, was incorporated also in his Summa. Pacetti (1953) proved that Olivi was the author of Tractatus, and Spicciani (1977) published the first part of the Latin Tractatus in a critical edition (cf. also the complete Italian translation of the Tractatus in Olivi [1990]); in 1980, the complete Latin edition of the Tractatus was published by Todeschini (Olivi 1980; Todeschini 1987) and in 2002, Piron provided a new Latin edition together with the French translation of the Tractatus (Olivi 2012). Meanwhile, there are also French, Portuguese, and English translations of Tractatus.

Olivi's Tractatus - which was written around the year 1293 - marks the beginning of something new. Evidence for this could be supplied by stressing several points, e.g., a theory of value, an inquiry on the "just price," and a distinction that we call "epoch making" today, namely the distinction between money (simplex pecunia) and capital (capitale). In the following sections, we focus on these three aspects and above all on the question of loaning money and the prohibition of interest (cf. Piron 1998, 2001; Ceccarelli 2016).

Why should we occupy ourselves with medieval economic ethics? Only to fill gaps in our knowledge of history or to get some orientation in a time where everybody is talking about the "End of Economics" - subtitle of a book by Henderson (1978/1989)? An author of the 13th century cannot tell us directly, of course, what we are doing wrong. In Olivi's lifetime, there were no banks, corporate groups, big industries, and stock exchanges. Concrete persons produced goods in manageable amounts and merchandized and lent money. They acknowledged a principle, which is a bare provocation for modern economics, but which nowadays seems worth of discussion: the prohibition of interest.

Loaning money to gain interest was forbidden in Judaism, Christianity, and Islam. It was stigmatized as "usury." Aristotle had declared that fertility of money was 
contrary to nature. ${ }^{1}$ The Catholic Church has not really abolished the prohibition of interest till now. But the economic development of modernity overran the antique, early Christian and medieval view of money. Money was simply fertile - until a few years ago everybody, pensioners as well as merchants, could expect their savings to bear "decent" interest. Only recently, things have changed. Is money, after all, not fertile? What is it that makes money fertile?

\section{The subjective theory of value}

According to Olivi, the economic value (valor usus) of something depends on its utility in satisfying human needs. It can be judged in a threefold way, as Olivi wrote in the first question of De emptione et venditione:

In turn, it must be known that this kind of value for things sold and used is measured in three ways. In a first way, [the value is measured] according to which a thing is better adapted and more effective for our utility (est nostris utilitatibus virtuosior et efficacior) from its own real qualities and properties; in this way, a good loaf of bread made from wheat is worth more to us as food than one made from barely, and a strong horse is worth more to us for transport or for combat than a donkey or a rouncy.

In a second way (the value is measured), according to which things are more necessary for us from their rarity or difficulty in being found (ex sue invencionis raritate et difficultate sunt nobis magis necessarie), since by their very scarcity, we have a greater need for them and less of an ability to get and use them. Accordingly, the wheat is worth more at the time of general shortage or famine and scarcity than at the time when it is in great abundance among all. And thus, the four elements, namely, water, earth, air, and fire, have a lower price among us on account of their supply than gold or balsam might, even though they are of themselves more necessary and useful for our life.

In a third way, the value of things is measured according to the greater and lesser pleasure of our will (beneplacitum nostre voluntatis) in having things of this kind. Indeed, to "use" (in the sense that it is taken here) is to take or to have something in the power of one's will; for that reason, not a small part of the value

1 Aristotle, Politics, I, 10 (1258 b 7 f.). Cf. Aristoteles Latinus 1961: Politica, edited by Petrus Michaud-Quantin, p. 18. Paris and Bruges: Desclée de Brouwer: "(...) tokos autem fit numisma numismatis: itaque et maxima preter naturam ista pecuniarum acquisitio est." of things for use is measured from the pleasure of the will - whether it is more or less pleased in using this or that thing and in having that thing at its disposal. Accordingly, one horse is more pleasing to one person and another horse to another, one ornament or jewel to one person and another to another; in this way, one person appraises highly something that is worthless to another and considers it precious and expensive, and vice versa. (Peter of John Olivi, A Treatise on Contracts, part I: On Purchases and Sales, First Question, sections 9-11, p. 3).

These three factors of value fixing can be formulated in the concepts of virtuositas, raritas, and complacibilitas, as Bernardino of Siena had put it in the margin of his manuscript of Olivi as well as in his Sermo $35 .^{2}$ These three expressions are well known to the historians of economic thought. According to Olivi, a thing is more valuable than another due to its virtuositas, because due to its special properties it is more useful and more suitable to satisfy our needs. In the second place, the economic value of a thing depends on its raritas, i.e., on its scarcity or rather its rareness and the difficulty in obtaining it. The third value fixing factor consists of the "beneplacitum" or complacibilitas, i.e., the individual, subjective pleasure in the possession and use of the thing. The introduction of complacibilitas as a factor of value is characteristic for Olivi; in comparison to former authors, it is a novelty and it looks like a modern theory of value. It introduces a strictly personal element in the analysis of value. Olivi related it to the use of a thing: indeed, the use of a thing constitutes for Olivi an action or rather a decision of free individual will. Complacibilitas, to be translated as "desiderability", "désidérabilité", or "Schätzbarkeit" i.e., "the desire for good or the degree of pleasure which one can derive from the good" (Chafuen 1986, p. 98) - expresses the idea of individual preference and subjective utility, whereas virtuositas refers to the objective qualities of a thing, i.e., its objective usefulness.

According to Olivi, the economic value of a thing rises and falls in proportion to its utility in satisfying human needs. In his response to the first question of De emptione et venditione, he stated that the value of a thing cannot be exact and always identical and that different prices for the same thing can be charged: on condition that 1 ) the value of a thing is consonant with the valuation which is measured "with respect to our use and according to the probable judgment of human

2 Bernardino of Siena: Tractatus de contractibus et usuris, in: Bernardinus Senensis: Quadragesimale de Evengelio Aeterno (Sermones 32-45), Opera omnia, studio et cura PP Collegii S. Bonaventurae ad fidem codicum edita, vol. IV, Florenz 1956, pp. 117-416, here p. $190 f$. 
estimation" (in respectu ad usum necessarium et ad probabilem iudicium humanae extimacionis) and 2) this valuation stays "within the limits of an appropriate latitude"3 (infra limites latitudinis competentis). Thus, Olivi put a limit to the individual valuation of goods.

\section{The question of just price and the common good}

Nevertheless, in the second question of De emptione et venditione, Olivi asked again the question of just price and of the role that offer and demand play in the estimation of just price. ${ }^{4}$ His question was as follows: can a price, in order to be just, be estimated according to the utility for the buyer (or receiver) of a benefit, i.e., according to a subjective utility - so, on the basis of an individual valuation of goods, as he had stated already in the previous Quaestio. He treated the problems aiming at commutative justice based on the equivalence of the exchanged things, respectively, on the equality of price and value of a good.

Olivi knew that individual ideas about the price often differ from the value of a thing and that each individual can have different ideas about the price of a thing. This can lead to trouble: besides the subjectivity and uncertainty of the valuation of goods, a further problem is that, in contract negotiations, both parties strive for a bigger profit or that one of the parties does so. According to Olivi, a purely individual valuation of goods can lead to a dilemma in determining the just price. It can lead even to the absurd situation that there is a disproportionately high price to pay.

Olivi made clear his view by means of some examples. As a starting point of his remarks, he referred to the emergency of a dying person who can be helped with a medicine, a medical plant, or - in a later example - a cup of water:

Second, it is asked whether a price can be set according to the value of the utility for those buying [something] or receiving some service in return for payment? For example, if a drink or medical herb has the value of freeing me from death and of restoring my health, which is beyond price, can the one who gives it justly demand from me a price equivalent to the healing, that is to say, beyond price? (Olivi 2016, part I: On Purchases and Sales, Quaestio 2, par. 21, p. 6).

In these cases, the value of the thing in question would correspond, for the ill person, to the utility he/she has

3 Olivi 2016, part I: On Purchases and Sales, First Question, section 13, p. 4.

4 Cf. the detailed commentary in Spicciani (1990b), to which we refer in the following. from it, that is, the recovery and salvation from possible death. Olivi rejected the idea that the seller of the goods, which restore the ill person's health, can charge from the receiver a price equivalent to the recovery, i.e., to the salvation from death.

Olivi denied that the subjective utility (the subjective valuation of goods) is a suitable basis for the estimation of the price of a vital good. His example makes clear that the value of human life is not to be quantified economically: it is invaluable. When we take Olivi's example of the life-saving cup of water, we can imagine that the seller, moved by excessive profit aspirations, would charge a price, which - in relation to the invaluable importance of life for the receiver - would be unaffordable. Thus, Olivi stated that

It must be said that if the price of things necessary for our life were to be set according to the equivalence of what they specifically confer upon us, the price of these things would be, as it were, beyond price. For in the case of one suffering from thirst and about to die if they do not have water, a cup of water is worth an infinite amount of gold and much more (Olivi 2016, part I: On Purchases and Sales, Second Question 2, section 24, pp. 6-7).

Exactly, such reprehensible behavior and profit orientation are to be avoided, said Olivi, because they jeopardize the existence of human community itself and damage feelings such as pity and solidarity. For Olivi, the final purpose (ratio finalis) of purchases and contracts is the realization of the common good. Thus, he declared that

Indeed, a refutation of [a counter-argument for] individual good is contained quite forcefully and quite broadly in this very argument, which can be elucidated all the more specifically from the proposed case. Because if I have the utmost need for a drink of water or for a little fire, I am obligated to give you as much as my life is worth, which is what these things confer upon me. By that same argument then, in a similar case, you will be obligated to give me as much for a drink of water, which would certainly be an unjust and unbearable burden. Moreover, this type of equity would root out at the core all compassion and humanity, and chiefly in cases that have need of even greater compassion and humanity. And may it never happen that virtuous and true equity should thus oppose compassion and the common bond of all humanity! (Olivi 2016, part I: On Purchases and Sales, Second Question, section 25, p. 7.)

Olivi went further still and postulated that the price of a good is estimated with a view of the common good; 
on the occasion, "the estimation commonly done by civil communities" (communis taxacio et estimacio) should be considered (Olivi 2016, part I: On Purchases and Sales, Second Question, section 26, p. 7). He gave four criteria of general valuation which ought to be considered in this communis taxacio et estimacio with a view to the common good, to estimate the prices (cf. Second Question, sections 27-34, pp. 7-9).

1) "A certain natural order of things for use" (Second Question, section 27, p. 7) (quemdam naturalem ordinem rerum utibilium); 2) the amount of a certain good available in a community, hence its scarcity or abundance (copie et inopie, seu paucitatis et habundancie), and the difficulty to procure ${ }^{5}$ this good; 3 ) the labor, the economic risk, and the industriousness in making good or services available. Olivi underlined the importance of industria that can be translated as "skill," "competence," and "effort." He wrote that "merchandise which likewise requires greater industriousness is generally estimated at a higher price as well, all things being equal. And although they work more with their body, a ditch-digger or stone-cutter is not given a price [for their work] like that of the architect, who with higher expertise and industriousness orders and directs the ditch-digger and stone-cutter as to what must be done." (Second Question, section 30, p. 8); 4) "the general degree and the order of offices and the dignities associated with them" (Second Question, section 31, p. 9). Olivi thus took into account the performance of office holders and justified wage differentials, because higher offices usually call for higher expenses - therefore, the military leader deserves a higher wage than the simple soldier. A military leader should be paid better because his performance requires higher industria, more experience and know-how, and a greater mental effort than those of the simple soldier. Furthermore, these abilities are acquired by long, intense, expensive, and risky studies - and the eligible persons are rare, and there are only few of them (cf. Second Question, section 32, p. 9).

According to Olivi, these four criteria have to be observed in the estimation of prices. Every single person should follow the general valuations and appraisals to avoid harmful and incorrect conduct; nobody should act against the common good and the community, thereby damaging the general use and justice. Olivi finally stated that "(...) the price of things for use is measured with respect to our use within the order of and in relation to the common good and the common use of a thing, and not in relation to something contrary or harmful to them"

5 Cf. Olivi 2016, part I: On Purchases and Sales, Second Question, section 29, p. 8: "Indeed, the more rare and difficult it is for us to get (rarius and difficilius aliquid adire) to and to have something, the more we estimate it to be something quite wonderful and even high beyond our means."
(Olivi 2016, part I: On Purchases and Sales, Second Question, section 36, pp. 9-10).

The common good (commune bonum) and the social esteem (communis estimacio) are the basis of just contract negotiations within a society. In Olivi's remarks, the economic value, from a very subjective level, turns into a common perspective based on the communis usus and the common use of the thing. The subject is no more an individual, which lives in isolation, but a person in a community who considers the well-being of others.

Olivi's shift from an individual valuation of goods to a meta-individual, common valuation of goods allows for the overcoming of difficulties that result from the dilemma of a merciless, not human-related equivalence of traded goods - as Olivi illustrated with the example of the cup of water that saves a person's life and therefore is equivalent to a human life. However, this takes for granted the modern concept of market as "place of exchange" (city, village, communitas) - a place, where offer and demand meet and where prices are fixed very concretely. For it is on the market that communis taxacio et estimacio become manifest. Without this hypothesis in the background, it would be indeed impossible to grasp the factors of price fixing, which gain their economic relevance only within the spatiotemporal perspective.

\section{On usurious contracts}

A very original idea developed by Olivi is his theory of capital where he distinguished between the merely sterile money and the fertile and lucrative money which he called as capital. ${ }^{6}$ By his theory, revolutionary at that time, Olivi questioned the current idea of money as simply a means of exchange. He acknowledged the legitimacy of trade and the added value (valor superadiunctus) of capital as well as admissible interest revenues (in the sense of a claim of interest as compensation, cf. par. 6).

Before expounding the aforementioned distinction between "money" and "capital," Olivi dedicated himself to a careful and convincing argumentation in several parts to show that to loan money with interest constitutes a grave sin, destroys the links of every human community, eliminates faith, and ultimately leads to hell. The greatest damage caused by the usurer is the damage he inflicts on himself, on his own soul. Spontaneously, one thinks of the saying of Péguy (1914) who wrote regarding a related phenomenon - saving: "Who saves money is a waster of what he has sold in order to get this money. The miser is wasteful. [...] He wastes

6 Olivi 2016, part III: Points Regarding the Matter of Usurious Contracts, Sixth Point, section 63, p. 57. 
and squanders his soul which he has sold for nothing, for money" (Péguy 1961, p. 1499).

Now, let us look a little closer to Olivi's arguments against interest. Overall, five groups of arguments are put forward:

1. Seven arguments from the holy scriptures

2. Eight arguments based on the authority of the fathers of the church and the popes

3. Seven arguments based on reason

4. Seven arguments in a reflection about the wickedness of usury from the standpoint of phenomenology/moral theology (the first of these arguments is tripartite, so there are three plus six arguments)

5. Finally, nine counterarguments to answer the nine arguments that initially - according to the structure of a scholastic Quaestio - had questioned the prohibition of interest

Taken altogether, these are 40 arguments

Hence, it is not the case that Olivi paid only a lip service to the prohibition of interest to distance himself from it afterward. On the contrary, it will be hard to find a scholastic who worked so much to confirm the badness of charging interest. We quote only the seventh argument (the number 7 often plays a special role in Olivi), in which the reflection on the badness of usury culminates:

Following from this and seventh, it [usury] causes the destruction of the Catholic faith, namely so that people do not believe that there is another life, that usuries are a sin, or that one will undergo a judgment of eternal damnation for these or for other things. From which ultimately follows a fall headlong into the infernal abyss of every crime and debauchery. We not only deduce the aforementioned things from reason, but we also confirm them with all too continual experience (Olivi 2016, part II: On Usurious Contracts, Eighth Question, section 49, p. 34).

\section{Simplex pecunia and capitale: the distinction between "money" and "capital"}

Olivi did not question the prohibition of interest; nevertheless, he paved the way for a thought which could serve to justify 700 years of capitalism. In addition to the section "On Usurious Contracts" (De contractibus usurariis) he developed, as Piron said, "the most striking conceptual innovation of the treatise." ${ }^{\prime 7}$ This innovation surely is

7 Sylvain Piron, Introduction to Olivi 2012, p. 67 (l'innovation conceptuelle la plus frappante du traité). not due to any crypto-capitalistic sympathies sometimes attributed to Olivi - unjustly he was called "one of the most outspoken defenders of Italian capitalism" (Kirshner 1972 , p. 81, quoted by Wolff [1978], p. 175, n. 27) - but rather to his unprejudiced view of economic evolutions.

Let us now come to the announced distinction of simplex pecunia and capitale. Money is not the same as money that one could say; more precisely, not all money is capital. Olivi illustrated this with an example. Suppose someone has decided to bring his grain to the market not immediately, but to sell it later when probably a higher price is realizable - that means, when its value is higher. In this situation, another person approaches him begging to sell the grain now. Olivi thought that the owner of the grain can charge the higher price expected for the later date even now without exposing himself to the reproach of usury, because:

(...) that thing, which in the firm resolution of its owner is ordered [firmo proposito domini sui est ordinatum] to some probable profit, not only has the simple character of money [simplicis pecunie] or of a good, but also, besides this, a certain seminal character of profit [racionem seminalem lucri] which we commonly call "capital". And for that reason, not only the simple value of the thing ought to be returned, but also the superadded value [valor superadiunctus] (Olivi 2016, part III: Points Regarding the Matter of Usurious Contracts, Sixth Point, section 63 , p. 57 ).

Olivi acknowledged the moral justification of the idea of commercial capital. He saw that the "interesse" as economic reality is different from "usura" (usury) - under the condition that the "interesse" does not stem from a simple amount of money, but from a capital invested already in trade, or foreseen for trade. By "capital," he meant the amount of money or goods chosen for a lucrative business (as for instance trading) and which are endowed with profitability. This profitability or the potential gain entails that the price for "capital" is higher than the value of simple money, which serves as its measure.

Thus, the ratio seminalis lucri, the lucrativeness, bestows a valor superadiunctus, an added value, on simple money. Therefore, "simple money" (simplex pecunia) relates to capital as the "simple value" (simplex valor) to the sum of simple value and added value (valor superadiunctus). By the way, it is noticeable that Olivi introduced this expression just 600 years before Marx. In both cases, the production of surplus or added value is essential for the functioning of capital. But there is also a difference: the surplus value in Olivi is not due to the exploitation of underpaid factory workers, but to the spirit of enterprise and the know-how of the skilled tradesman. 
How is it that a thing acquires added value? How does simple money change into capital? We have to take a step backward in the text. Olivi depicted a case taken from the common merchant practice of his time.

A tradesman has a good business idea, but he has no money to realize it. He raises a loan, expecting firmly to generate profit with his idea. Let us imagine that a ship is equipped to bring spices from the near East to Europe. Here, they are legitimately sold to a higher price than that paid for in the country of origin. Legitimately, because the activity of a tradesman is not per se sinful; rather he renders a service ${ }^{8}$ to society fetching the spices. The lender on his part participates in the gain with a fixed amount or a fixed profit share: the tradesman so to speak buys the future profit from him, because he expects that the whole business is advantageous for both of them. Here, the rule applies "the capital in trading is at the risk of the investor" (capitale currit in mercando ad periculum tradentis). It is obvious that here the money invested in a certain business (i.e., the capital) differs from "normal money."

First, "it is something assigned for profitable commerce"10 (Iucrativis mercacionibus destinatum). Second, the investor assumes the risk when the enterprise fails, e.g., if the ship sinks or falls into the hands of pirates. Therefore, the situation is quite different from the condition of the small saver who brings his money to the bank and charges an added value for it without engaging in a concrete venture. Moreover, the bank customer expects a guarantee for his deposit account; he is far from assuming the risk of the entrepreneur.

\section{The extrinsic titles of "interesse"}

Olivi's opinions about capital and the question of interest are embedded in the theological-canonistic debate which came up in the first decades of the 13th century and grew more acute in the following centuries. The question was as follows: Is it admissible, despite the prohibition of usury, to make a difference between any sum of money which is loaned and a loan that consists in a sum of money invested already in an enterprise or to be invested in a lucrative trade? This last-mentioned sum of money seemed indeed to hold a legitimate profit expectation.

On the one hand, every increase in money obtained by a loan was to be considered as usury. On the other hand, the compensation charged by a tradesman or by the person who intended to invest money for withdrawing

8 Cf. Olivi 2016, part I: On Purchases and Sales, Sixth Question, sections 69-79, pp. 18-20.

9 Olivi 2016, part III: Points Regarding the Matter of Usurious Contracts, Fourth Point, section 35, p. 49.

10 Olivi 2016, part III: Points Regarding the Matter of Usurious Contracts, Fourth Point, section 47, p. 52. the money from a business to loan it to another was considered rather as compensation of a damage incurred. In addition, such a loss or damage that includes the three components such as lucrum cessans (profit foregone), damnum emergens (positive damage), and periculum sortis (risk of capital loss) was called as "interesse" - an expression from Roman law.

Therefore, usura is what is charged for the loan in virtue of the loan (quidquid sorti accedit vi mutui), whereas "interesse" stands for the compensation (id quod interest) and is justified and legitimated not in the loan in itself, but in circumstances extrinsic to the loan which cause an economic damage to the lender and for which the borrower has to compensate him. Among the extrinsic titles of "interest," one finds in medieval terminology damnum emergens, i.e., the concrete damage for the lender which occurs because he cannot dispose of the sum lent to the borrower; furthermore, lucrum cessans, the foregone profit that occurs when the lender at the date of the signing of the contract would have had an alternative possibility of investment that he renounced, although it would have been advantageous and lucrative for him, and eventually periculum sortis, the risk of capital loss, for instance, when the borrower is unable to meet his liabilities to pay.

Olivi wrote that ${ }^{11}$

Also, from this, it is clear that when someone loans to another money that they firmly intend to trade, from compassion alone and the need of that person, [but] under such a pact that the lender will profit or lose as much as a similar sum will profit or lose with an equivalent such merchant, they do not commit usury, but rather do a certain favor with their indemnity preserved, just as has been shown more fully in a particular quodlibetal question. ${ }^{12}$

Thus, Olivi frankly took the part of those who acknowledged the agreement on profit (=compensation for the profit or to avoid damages) before stipulating a loan as legitimate:

(...) if the lender was about to trade beforehand with the money lent, or about to acquire some licit profit from it by paying and buying or about licitly save themselves from some imminent damage, and when brought to this by compassion for fraternal need alone and at the insistence of the other's requests, they handed over their money on the condition that the other should be obligated

11 Olivi 2016, part III: Points Regarding the Matter of Usurious Contracts, Sixth Point, section 64, p. 57.

12 Here, Olivi refers to Quodlibet I, 17 (Olivi 2002). 
to compensation as interest for the aforementioned profit or damage to them, then something beyond the money loaned is licitly demanded and received, but not something worth more, inasmuch as the aforementioned money already had in itself, as it were, the force and value of this compensatory interest (Olivi 2016, part II: On Usurious Contracts, Eighth Question, section 51 p. 34).

From the quoted passages, it clearly emerges that for Olivi there are two conditions that have to be fulfilled to consider a sum of money or goods as capital: 1) it is necessary that the sum of money or good is foreseen for a lucrative trade and 2) that this happens with a precise intention, a firm purpose (firmo proposito), i.e., that there is an inner disposition toward a proper investment activity. In this way, Olivi underlined the subjective element: there must really be the intention to invest one's own money in business.

\section{Ratio seminalis and capitale in the context of theory of impetus}

Olivi used a technical term from the stoic tradition (it played a prominent role also in Augustine) to characterize capital: ratio seminalis. This is not only "a nice allusion to patristic philosophy", as Langholm, the great Norwegian scholar of medieval economic theories, supposed (Langholm 1992, pp. 345-373, here p. 373).

The German philosopher Wolff gave a - convincing, as it seems - hint to a parallel, which theoretically backed Olivi's thesis of valor superadiunctus and ratio seminalis, respectively. It was not by chance that Olivi was a genial innovator in several fields at once. The "added value" inherent in capital (and absent in simple money) can be compared with the impetus of a thrown stone (and absent in the unmoved stone. The theory of impetus replaces the Aristotelian theory of violent motion. The theory of impetus says that by throwing a stone, the mover conveys a force to the stone - the impetus - which makes that the stone for a while is moved, as it were, on his own.

The ratio seminalis which makes that simple money becomes capital is similar to the "impetus" which lets fly the - otherwise motionless - stone. The locus classicus where Olivi treated the theory of impetus is Quaestio 31 of the Quaestiones in secundum librum Sententiarum. Here, the rationes seminales occur already in the title. ${ }^{13}$

13 Olivi: "Nono qaeritur an omnia quae educuntur de potentia materiae sint ibi prius secundum suas essentias seu secundum rationes seminales vel secundum potentias activas", in: Olivi 1922, Quaestiones in secundum librum Sententiarum, edited by Bernhard Jansen, vol. I, pp. 508-570.
The decisive aspect for us is summed up by Wolff (1994, p. $416 \mathrm{f}$.) in the following lines: ${ }^{14}$

In Quaestio 31, Olivi expresses the idea that in certain (...) processes of action, motion or generation there is a transmission of power: A capacity of form-giving (vis formativa) detaches itself as virtus from the form-giving creator or maker, from the acting subject (principalis agens) and continues to operate, disconnected from the primary agens, in the objects of motion or generation. As examples of processes of motion and generation, Olivi on the one hand uses motions of projectiles, on the other hand the generation of animals. Olivi's terminology is interesting. He calls the mediating power virtus instrumentalis (...) or ratio seminalis. It is just this concept of ratio seminalis, which occurs also in a decisive place in Olivi's ethics.

Wolff continued with the quotation from the Tractatus about "a certain seminal character of profit," the ratio seminalis lucri which makes the difference between capital and simple money (cf. above, par. 5).

Olivi's theory of money is rooted in his theory of physics; the concept of capital echoes the theory of impetus. The same idea is present also at the top of Olivi's natural philosophy, in his interpretation of the relation between soul and body. Olivi was a critic of Aquinas's doctrine of anima rationalis as the only form of the body. According to Olivi, it is nearer to the phenomena (and also to theological tenets) to concede to the body (also to the corpse) a form of its own.

Olivi conceived the relation of soul and body in a way that anima intellectiva is the last form perfecting the whole human, but is not immediately form-giving for the body. This subordination corresponds to the idea that on an ontologically deeper level there is a potentiality which can be activated from an ontologically higher level: so, money can become capital by the industry of the merchant, a stone can appropriate the impetus of

14 Cf. Olivi 1922, Quaestiones in secundum librum Sententiarum, edited by Bernhard Jansen, vol. I, p. 563: "Nam virtus formativa non agit nisi sicut virtus instrumentalis alicuius principalis agentis, sicut suo modo impulsus seu inclinationes datae proiectis a proiectoribus movent ipsa proiecta etiam in absentia proicientium (...)" What follows gives rise to doubt if "principalis agens" means really the acting subject, that is the person who throws the stone. It rather seems that the thrower is an "agens instrumentale" which educes ("educit") the possibility of motion out of the stone - a possibility installed there by the creator (Olivi 1922, Quaestiones in secundum librum Sententiarum, p.564). "Et causa huius est, quia plus fecit etiam in productione formae, sive sensitivae sive aliarum, qui creavit mobilitatem materiae [i.e. God] qua potest moveri ab hoc vel ab illo agente [i.e. the thrower] ad talem formam quam faciat ipse motor naturalis seu creatus." Olivi 1922, loc cit. 
the thrower, the anima sensitiva can be "informed" by the anima intellectiva. By way of example, mouth and tongue do not have per se access to the intellect, they cannot talk - but we can do so, elevating the potentials of our sensuality to a new level. Olivi wrote that ${ }^{15}$

Consequentially results that rather the whole intellectual soul is designated as the form of the body than only its sensitive part, because the form, simply speaking, rather means the total form than a part of it. Therefore it is more proper to say the man talks than the tongue, even though a man cannot talk but by his tongue - because an act is rather attributed to the total supposit than to a part.

\section{Conclusion}

The basis of Olivi's distinction between the legitimate idea of capital and the canonistic prohibition of interest is the intention behind the human actions. Including

15 Olivi 1924, Quaestiones in secundum librum Sententiarum, edited by Bernhard Jansen, vol. II, Quaracchi 1924, Quaestio 51. Appendix, p. 144. "Ex hoc etiam est quod tota anima rationalis dicitur forma sui corporis potius quam sola sua pars sensitiva, quia forma simpliciter dicta potius significat formam totalem quam partem ipsius, iuxta quod et magis proprie dicitur homo loqui quam lingua, quamvis homo non loquatur nisi per linguam, quia actio potius attribuitur toti sopposito quam parti." Cf. Schneider 1973, p. 226, n. 93.

\section{References}

Aristoteles Latinus, Politica, In: Michaud-Quantin P. (Ed.), Paris, 1961.

Bazzichi O., Economia e Scuola francescana: Attualità del pensiero economico e politico francescano, Padova, 2013.

Bazzichi O., Dall'economia civile francescana all'economia capitalistica moderna, Roma, 2015.

Bernardino of Siena, Tractatus de contractibus et usuris, In: Bernardinus Senensis, Quadragesimale de Evangelio Aeterno (Sermones 32-45): Opera omnia, studio et cura PP Collegi S. Bonaventurae ad fidem codicum edita, 4, Florenz, 117-416, 1956.

Bruni L., Smerilli A., Benedetta Economia: Benedetto di Norcia e Francesco d'Assisi nella Storia Economica Europea, Roma, 2009.

Ceccarelli G., II Tractatus de contractibus di Olivi nel discorso economico dei frati minori, In: Società Internazionale di Studi Francescani (Ed.), Pietro di Giovanni Olivi frate minore: Atti del XLIII Convegno internazionale (Assisi, 16-18 Ottobre 2015), Spoleto, 241-275, 2016. the intention in the ethical judgment, Olivi differentiated between "usura" and "interesse." Not the simple money, but the capital has "a certain seminal character of profit" and is lucrative. In addition, only if the holder intends to invest (or has invested already), the money becomes capital. The investment must not exist as a mere wish or a general possibility, but it has to be practically possible and implicate a concrete gain. Thus, Olivi, on the one hand, criticized the merely sterile money; on the other hand, he legitimated capital as money involved in a business or destined for trade. The use of this capital as a loan justifies to charge a compensation from the borrower - due to the lucrum cessans - in the form of an "interesse."

One of the main merits of Olivi's Tractatus is it to recall the nearly forgotten distinction between money and capital. We have seen an age of unprecedented, but often blind economic growth. Unjustly, the nations have been divided into poor and rich, and the achievements of modernity have been allocated in a very unequal way. Now, it seems advisable not to continue valuing money automatically as fertile. Rather, the risk entailed by investments should be imposed on those who realize expectable profits from them.

We do not want to turn back to the Middle Ages. But, we should grasp the opportunity to learn from the medieval philosopher thessential insights which were present to them and which we have lost.

Chafuen A.A., Christians for freedom. Late-Scholastic Economics, San Francisco, 1986.

De Roover R., Business, banking, and economic thought in late medieval and early modern Europe, Chicago, 1974.

Henderson H., Das Ende der Ökonomie. Die ersten Tage des nach-industriellen Zeitalters, München, 1978/1989.

Heusinger S.V., Die Zunft im Mittelalter. Zur Verflechtung von Politik, Wirtschaft und Gesellschaft in Straßburg, Stuttgart, 2009.

Höffner J., Wirtschaftsethik und Monopole im fünfzehnten und sechzehnten Jahrhundert, In: Nothelle-Wildfeuer U., Althammer J. (Eds.), Joseph Höffner: Wirtschaftsordnung und Wirtschaftsethik, 3, 33-118, Paderborn, 1941/2014.

Kirshner J., From Usury to public finance: the ecclesiastical controversy over the public debts of Florence, Genua and Venice (1300-1500), Ann Arbor, 1972.

Lambertini R., Ökonomische Lehre, In: Brungs A., Mudroch V., Schulthess P. (Eds.), Grundriss der Geschichte der Philosophie. Die Philosophie 
des Mittelalters, Bd. 4: 13. Jahrhundert, Basel, 1536-1548, 2017.

Langholm O., Economics in the medieval schools. Wealth, exchange, value, money and usury according to the Paris theological tradition 1200-1350, Leiden, 1992.

Langholm O., The legacy of scholasticism in economic thought. Antecedents of choice and power, Cambridge, 1998.

Langholm O., Olivi to Hutcheson. Tracing an early tradition in value theory. J Hist Econ Thought, 31, 131-141, 2009.

Melé D., Scholastic thought and business ethics. An overview. In: Lütge C. (Ed.), Handbook of the philosophical foundations of business ethics, 1, Ordrecht, 133-158, 2013.

Olivi P.I., Quaestiones in secundum librum Sententiarum, In: Jansen B. (Ed.), 1. Collegio di San Bonaventura, Firenze, 1922.

Olivi P.I., Quaestiones in secundum librum Sententiarum, In: Jansen B, (Ed.), 2. Collegio di San Bonaventura, Firenze, 1924.

Olivi P.I., Tractatus de emptionibus et venditionibus, de usuris, de restitutionibus. In: Giacomo Todeschini: Un trattato francescano di economia politica: il De emptionibus et venditionibus, De usuris, De restitutionibus di Pietro di Giovanni Olivi, Roma, 51-112, 1980.

Olivi P.I., Usure, compere e vendite. La scienza economica del XIII secolo, Milano 1990.

Olivi P.I., Quodlibet I, quaestio XVII, In Petri Iohannis Olivi Quodlibeta quinque, curavit Stephanus Defraia, Ed. Collegii S. Bonaventurae ad Claras Aquas, Grottaferrata, Roma, (Collectio Oliviana 7), 58-63, 2002; French translation in: Pierre de Jean Olivi, Traité des contrats. Présentation, édition critique, traduction et commentaires par Sylvain Piron, Les Belles-Lettres, Paris, (Bibliothèque scolastique 5), 395-401, 2012.

Olivi P.I., Traité des contrats. Présentation, édition critique, traduction et commentaires par Sylvain Piron, Paris, 2012.

Olivi P.I., Lectura super Apocalypsim, In: Lewis W. (Ed.), Latin text with English introduction, St. Bonaventure, New York, 2015.

Olivi P.I., A treatise on contracts. Critical edition and commentary by Sylvain Piron, translated from the Latin by Ryan Thornton and from the French by Michael Cusato, St. Bonaventure, New York, 2016.

Pacetti D., I codici autografi di S. Bernardino da Siena della Vaticana e della Comunale di Siena, Archivum Franciscanum Historicum, 29, 501-537, 1936.
Pacetti D., Un trattato sulle usure e le restituzioni di Pietro di Giovanni Olivi, falsamente attribuito a Fr. Gerardo da Siena, Arch Franciscanum Historicum, 46, 448-457, 1953.

Péguy C., Note conjointe sur M. Descartes et la philosophie cartésienne (1914), In: CEuvres en Prose II, Paris, 1357-1552, 1961.

Piron S., Marchands et confesseurs. Le Traité des contrats d'Olivi dans son contexte (Narbonne, fin xiiie-début xiv siècle), In: L'Argent au Moyen Âge. XXVIII Congrès de la SHMESP (Clermont-Ferrand, 1997), Paris, 293-308, 1998. Available at: http:// www.persee.fr/doc/shmes_1261-9078_1998_ act_28_1_1729 (consulted on 18.02.2016).

Piron S., Perfection évangélique et moralité civile. Pierre de Jean Olivi et l'éthique économique franciscaine, In: Molina B., Scarcia G. (Eds.), Ideologia del credito fra Tre e Quattrocento: dall'Astesano ad Angelo da Chivasso. Atti del convegno internazionale (Asti 2000), Asti, 103-143, 2001.

Schneider T., Die Einheit des Menschen. Die anthropologische Formel „anima forma corporis“ im sogenannten Korrektorienstreit und bei Petrus Johannis Olivi. Ein Beitrag zur Vorgeschichte des Konzils von Vienne, Münster, 1973.

Spicciani A., La mercatura e la formazione del prezzo nella riflessione teologica medioevale. Memorie Classe di Scienze morali, storiche e filologiche, 20, Roma, 1977.

Spicciani A., Capitale e interesse tra mercatura e povertà nei teologi e canonisti dei secoli XIII-XV, Roma, 1990a.

Spicciani A., Pietro di Giovanni Olivi indagatore della razionalità economica medievale, In: Spicciani A., Vian P., Andenna G. (Eds.), Pietro di Giovanni Olivi: Usure, compere e vendite. La scienza economica del XIII secolo, Milano, 21-72, $1990 \mathrm{~b}$.

Todeschini G., "Oeconomica franciscana": Pietro di Giovanni Olivi come fonte per la storia dell'eticaeconomica medievale, In: Capitani O. (Ed.), Una economia politica nel Medioevo, Bologna, 59-91, 1987.

Todeschini G., II prezzo della salvezza. Lessici medievali del pensiero economico, Roma, 1994.

Todeschini G., Ricchezza francescana. Dalla povertà volontaria alla società di mercato, Bologna, 2004.

Wolff M., Geschichte der Impetustheorie. Untersuchungen zum Ursprung der klassischen Mechanik, Frankfurt a.M., 1978.

Wolff M., "Mehrwert und Impetus bei Petrus Johannis Olivi", In: Miethke J., Schreiner K. (Eds.), Sozialer Wandel im Mittelalter, Sigmaringen, 413-423, 1994. 